J.L. Beal MD, M. Freysz MD, G. Berthelon MD, P. D'Athis DSc, S. Briet MD, M. Wilkening MD

\title{
Consequences of fluid absorption during transurethral resection of the prostate using distilled water or glycine 1.5 per cent
}

This prospective and randomized study compared the consequences of two irrigating fluids, distilled water and glycine for transurethral prostatectomy. Forty-nine consecutive unselected patients undergoing transurethral resection of the prostate with spinal anaesthesia were investigated. The irrigating fluid was either distilled water (group A, 24 patients) or glycine 1.5 per cent (group B, 25 patients). The absorption of irrigating fluid was measured, all surgical events and any clinical signs of TURP syndrome during and after surgery were recorded. Early signs of TURP syndrome were observed in one patient in group $A$ and in four in group $B$ without further consequence. From all the biological variables, only plasma protein concentration, haematocrit, free plasma haemoglobin and free bilirubin concentrations were found to have changed. Plasma protein concentration and haematocrit decreased significantly during and after surgery in the two groups. Free plasma haemoglobin increased significantly with time: a significantly higher concentration was observed in group $A$ than group $B$. Free bilirubin concentration increased with time in the two groups and was statistically greater in group A. With the two irrigating fluids, we observed a significant amount of haemolysis and haemodilution without clinical consequences. A low irrigating fluid pressure, a short resection time, and the use of spinal anaesthesia seems to us to be essential. Close observation of patients following transurethral prostatectomy is needed but the choice of the irrigating fluid does not seem to be important.

\section{Key words}

COMPLICATIONS: TURP syndrome; FLUIDS, IRRIGATING: glycine, water; SURGERY: urologic, prostate; SYNDROMES: TURP.

Département d'Anesthésie-Réanimation and Service d'Urologie, Hôpital Général, and Département d'Informatique Médicale, Hôpital du Bocage, 21033 Dijon Cédex, France. Address correspondence to: Dr J.L. Beal, Département d'Anesthésie-Réanimation, Hôpital Général, 21033 Dijon Cédex (France).
An adequate view of the prostate during transurethral prostatectomy (TURP) requires the use of an irrigating fluid. Excessive intravascular or extravascular uptake of this fluid during TURP is a classical complication (transurethral resection reaction: TURP syndrome). When distilled water is used, absorption through the prostatic venous plexus may cause intravascular haemolysis and acute renal failure ${ }^{1,2}$ Alternatively, the absorption of glycine 1.5 per cent provokes occasional hyperammonaemia, ${ }^{3,4}$ hyperoxalaemia and hyperoxaluria which are responsible for acute renal failure and anuria. ${ }^{5}$ The use of distilled water is common in our surgical unit. The aim of this study was to compare the clinical and biological effects of these two irrigating fluids.

\section{Methods}

After informed consent was obtained, 49 consecutive unselected patients undergoing TURP were investigated. The choice of the irrigating fluid, distilled water or glycine 1.5 per cent was made by drawing lots: group A (distilled water) 24 patients, group B (glycine 1.5 per cent) 25 patients.

The day before surgery, the following measurements were made in each patient: plasma protein, full blood count, haematocrit, free plasma haemoglobin, haptoglobin, alpha-1-acid-glycoprotein, plasma total bilirubin, free and bound bilirubin, plasma electrolytes, blood urea nitrogen, plasma creatinine, plasma osmolality and mid stream urine culture.

In addition to the usual surgical monitoring all patients had a central line placed prior to the start of surgery for sampling of mixed venous blood and for monitoring CVP. Anaesthesia was provided with $15 \mathrm{mg}$ subarachnoïd hyperbaric bupivacaine using a standard technique. Intravenous isotonic saline $(250 \mathrm{ml})$ was administered during surgery. Metaraminol was given when necessary to reverse hypotension caused by the spinal anaesthesia.

The TURP was carried out using an Iglesias alternating current resector without aspiration or suprapubic drainage 
TABLE I Comparative data on the two groups (mean \pm SEM)

\begin{tabular}{|c|c|c|c|c|}
\hline & $\begin{array}{l}\text { Age } \\
\text { (yrs) }\end{array}$ & $\begin{array}{l}\text { Prostate } \\
\text { resected }(g)\end{array}$ & $\begin{array}{l}\text { Fluid } \\
\text { absorption } \\
(\mathrm{ml})\end{array}$ & $\begin{array}{l}\text { Blood loss } \\
\text { (ml) }\end{array}$ \\
\hline $\begin{array}{l}\text { Group A } \\
\quad \text { (distilled water) }\end{array}$ & $74 \pm 1.8$ & $22 \pm 0.5$ & $360 \pm 112$ & $129 \pm 34$ \\
\hline $\begin{array}{l}\text { Group B } \\
\text { (glycine } 1.5 \% \text { ) }\end{array}$ & $\begin{array}{c}73.8 \pm 1.7 \\
\text { NS }\end{array}$ & $\begin{array}{l}18 \pm 0.3 \\
\text { NS }\end{array}$ & $\begin{array}{l}464 \pm 97 \\
\text { NS }\end{array}$ & $\begin{array}{c}124 \pm 31 \\
\text { NS }\end{array}$ \\
\hline
\end{tabular}

technique. During TURP, $3 \mathrm{~L}$ bags of irrigating solution were installed at a height of $60 \mathrm{~cm}$ above the patient. The irrigating fluids were collected in a bag by gravity via waterproof operative drapes. Blood loss was calculated by the concentration of haemoglobin in the collected irrigating fluid. If the irrigating fluid output, corrected for blood loss, exceeded the input, the fluid balance was given a negative value; positive values indicated absorption.

The blood measurements as those taken before surgery were repeated in the operative period (T2) $\left(\frac{1}{2} h\right.$ after the beginning of the procedure) and the prostatic tissues were weighed. Surgical events and any clinical signs of TURP syndrome were recorded. Classical treatment was commenced immediately when early signs of TURP syndrome (confusion, headache, nausea, vomiting, dizziness) were observed. Hypertonic saline, three per cent was administered IV in group A, with the addition of furosemide in group B.

Following the operation each patient retumed to the ward with a continuous irrigation of isotonic saline for 18 to 48 hours. At the third postoperative hour (T3) and the morning after TURP (T4), the blood measurements were repeated.

Statistical analysis was by Chi-square analysis completed by the Fisher exact test to confirm the homogenous pre- and peroperative distribution of the two groups. Further statistical analysis for continuous variables was by analysis of variance for repeat measures and for discontinuous variables Chi-square analysis was used. All the variables were compared with time and between groups.

\section{Results}

The results of this study are shown in Tables I and II and Figures 1 to 4 . Table I shows that both groups were comparable in terms of mean age, weight of prostate resected, fluid absorption and blood loss.

There was no significant difference in the degree of hypotension between the two groups in the operative period. An average maximum decrease in systolic arterial pressure of 5-12 per cent was observed in both groups within $20 \mathrm{~min}$ of the induction of spinal anaesthesia.

Two venous sinus and four capsule perforations were noted by the surgeon in group $\mathrm{A}$, with two showing postoperative hypovolaemia, anaemia $\mathrm{Hb}<8 \mathrm{~g} \cdot 100 \mathrm{ml}^{-1}$, tachycardia $\mathrm{HR}>120$ beats $\cdot \min ^{-1}$, systolic arterial pressure $<100 \mathrm{mmHg}$, oliguria and negative CVP. In group B, three capsular and one venous sinus perforations were noted, which resulted in one patient developing non-oliguric acute renal failure (capsular perforation). Early signs of TURP syndrome were observed in one patient in group A (without venous sinus or capsular perforation) and in four patients in group B (2 capsular perforations) without further consequences (Table B). In each of the patients there was bradycardia (HR $<40$ beats ' $\min ^{-1}$ ), systolic hypotension ( $<70 \mathrm{mmHg}$ ), massive fluid absorption and large decrease in haematocrit and plasma protein concentrations. However, after therapy (three per cent hypertonic saline solution), we observed minimal changes in plasma sodium concentration (decrease of $\left.9 \mathrm{mmol} \cdot \mathrm{1}^{-1}\right)$ and osmolality $\left(10 \mathrm{mosm} \cdot \mathrm{kg}^{-1}\right)$. No complications were noted in the postoperative period.

When all the biological variables were compared, only the plasma protein, haematocrit, free plasma haemoglobin and free bilirubin concentrations were found to have changed statistically. Indeed, we observed no statistically significant changes with time for plasma sodium, osmolality, blood urea nitrogen, plasma creatinine, plasma total bilirubin, haptoglobin or alpha-1-acid-glycoprotein concentrations.

Figure 1 shows that the change of plasma protein concentration was statistically significant $(P<0.01)$ in group $\mathrm{A}$ and $\mathrm{B}$ during and after surgery. However, this variable was statistically higher at $\mathrm{T} 1$ in group $\mathrm{A}$.

Figure 2 shows that the decrease in haematocrit

TABLE II Five cases of TURP syndrome

\begin{tabular}{|c|c|c|c|c|c|}
\hline Case $n^{\circ}$ & Irrigating fluid & $\begin{array}{l}\text { Fluid } \\
\text { absorbed } \\
m l\end{array}$ & $\begin{array}{l}\text { Haematocrit } \\
\text { decrease } \\
\%\end{array}$ & $\begin{array}{l}\text { Protein } \\
\text { decrease } \\
g \cdot L^{-1}\end{array}$ & Observations \\
\hline 15 & Water & 1250 & 9.7 & 22 & None \\
\hline 27 & Glycine $1.5 \%$ & 1500 & 7.7 & 10 & Venous sinus \\
\hline 30 & Glycine $1.5 \%$ & 1000 & 9.1 & 15 & None \\
\hline 32 & Glycine $1.5 \%$ & 1000 & 8.7 & 11 & None \\
\hline 44 & Glycine $1.5 \%$ & 1000 & 9.7 & 20 & None \\
\hline
\end{tabular}




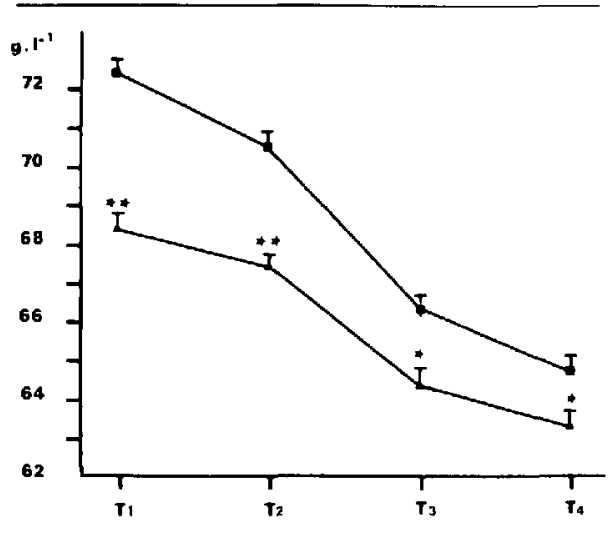

FIGURE 1 Plasma protein concentrations (mean \pm SEM) $g 1^{-1}$ at T1, T2, T3, T4; 1.5 per cent. $* \mathrm{P}<0.05, * * \mathrm{P}<0.01$.

concentrations was significantly different $(P<0.05)$ with time but not between the two groups.

Figure 3 shows that the free plasma haemoglobin concentration increased in the two groups $(P<0.05)$. We observed statistical differences between the two groups at $\mathrm{T} 2$, and $\mathrm{T} 4$ ( $\mathrm{P}<0.05$ ). In our laboratory, plasma haemoglobin concentrations up to $5 \mathrm{mg} \cdot 100 \mathrm{ml}^{-1}$ are considered normal. Abnormal values were found in 90 per cent in group A and 64 per cent in group $B$. In only seven patients did the level exceed $50 \mathrm{mg} \cdot 100 \mathrm{ml}^{-1}$. The highest values were $220 \mathrm{mg} \cdot 100 \mathrm{ml}^{-1}$ in group $A$ and 65 $\mathrm{mg} \cdot \mathrm{ml}^{-1}$ in group $\mathrm{B}$.

Figure 4 shows that free bilirubin concentration increased with time in both groups $(P<0.01)$ and was statistically higher in group A than $B(P<0.01)$.

\section{Discussion}

In our practice distilled water is preferred to nonhaemolytic irrigating solutions such as glycine because of better visibility. For this reason, a double-blind study was not possible. Nevertheless we observed no more operative incidents or bleeding using glycine 1.5 per cent than with distilled water. Despite numerous studies and investigations ${ }^{6-10}$ the cause of the TURP syndrome and associated complications from absorption remains unclear. Creevy and Reiser ${ }^{1}$ maintain that intravascular haemolysis is the chief offender. Others " have shown that absorption can result in acute water intoxication with hypoosmolality and dilutional hyponatraemia. Oester and Madsen ${ }^{6}$ showed that absorption occurs not only directly through open prostate venous sinuses, but also into extravascular sites through small perforations of the bladder or through

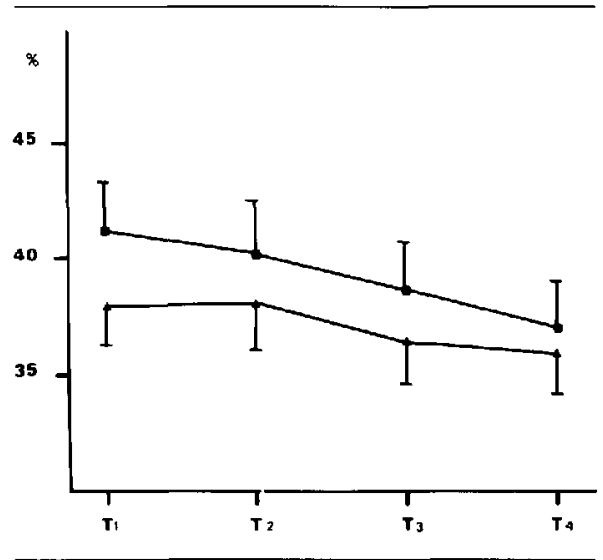

FIGURE 2 Haematocrit per cent (mean \pm SEM) at T1, T2, T3, T4; distilled water, $\mathbf{A} \mathbf{A}$ glycine 1.5 per cent. ${ }^{*} \mathrm{P}<0.05,{ }^{* * P}<0.01,{ }^{* * *} \mathrm{P}<0.001$.

defects in the prostatic capsule. These authors found that more than two thirds of absorption occurred extravascularly. The absorbed volumes are very variable, and range from 237 to $996 \mathrm{ml},{ }^{6}$ although a figure of $20 \mathrm{ml} \cdot \mathrm{min}^{-1}$ has been suggested as an average. ${ }^{7}$

Irrigating fluids are not physiological as they contain no electrolytes. Therefore their use may disturb the physiology of the intracellular and extracellular compartments. In our study, significant haemolysis was observed in both groups, and was greater in the distilled water group. However it was not severe and was comparable with other studjes. $^{8,10}$ A progressive increase of free bilirubin concentration confirmed extravascular haemolysis. We measured the osmolality of glycine 1.5 per cent which was $188 \mathrm{mosm} \cdot \mathrm{kg}^{-1}$, (a 2.1 per cent solution is isoton$i^{7}$ ), and is comparable with that described by Madsen ${ }^{12}$ and to the osmolality of cytal (a mixture of sorbitol 2.7 per cent and mannitol 0.54 per cent). Thus, when either distilled water or other hypotonic fluids, including glycine 1.5 per cent, are used the danger of haemolysis exists. Nevertheless the danger of a high free haemoglobin concentration due to haemolysis following TURP seems to have been over-emphasized in the past. ${ }^{12}$ In the absence of hypovolaemia, acidosis or sepsis, haemolysis is unlikely to cause acute renal failure. ${ }^{13,14}$ Our five patients with early signs of TURP syndrome were seen after both water and glycine, but there were no sequelae. All demonstrated absorption of irrigating fluid: with mild haemodilution, and decreases in plasma protein and haematocrit concentrations but no hypo-osmolality or hyponatraemia (Table II). Usually, there is no correlation 


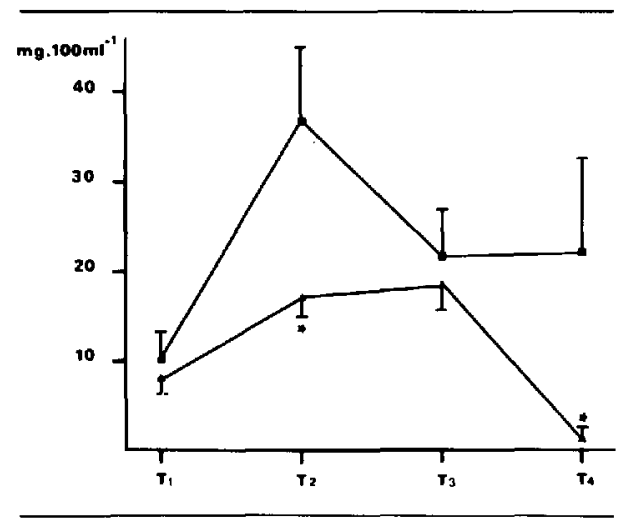

FIGURE 3 Free plasma haemoglobin concentration, $\mathrm{mg} \cdot 100 \mathrm{ml}^{-1}$, (mean $\pm \mathrm{SEM}$ ) at $\mathrm{TI}, \mathrm{T} 2, \mathrm{~T} 3, \mathrm{~T} 4 ; \mathrm{C}$

$\Delta$ glycine 1.5 per cent. ${ }^{*} \mathrm{P}<0.05,{ }^{* *} \mathrm{P}<0.01,{ }^{* * *} \mathrm{P}<0.001$.

between the amount of fluid absorbed and the serum sodium concentration ${ }^{15}$ or the CNS symptoms. ${ }^{16}$ When glycine is used, the cerebral symptoms may be the result of a direct neurotoxic effect of glycine, in the absence of significant changes in either serum sodium concentration or osmolality. ${ }^{17}$ When distilled water is used, the clinical picture may be the result of haemolysis and may be difficult to differentiate from that of a transfusion reaction. ${ }^{18}$ Currently the most popular irrigating fluid is 1.5 per cent glycine. However, this solution is not isotonic and numerous complications have been described with its use including: hyperoxalaemia, ${ }^{5}$ hyperammonaemia, ${ }^{3,4}$ amino-acid metabolism derangements, ${ }^{17}$ cardiovascular complications ${ }^{19-22}$ and visual disturbances. ${ }^{23}$

The choice of irrigating fluid does not seem to be important. Attempting to reduce the amount of fluid absorbed by reducing the head of pressure of the irrigating fluid, ${ }^{24}$ and limiting the operative time to 60 minutes whenever feasible ${ }^{24}$ have been successful. (Despite this, cases of toxicity have been reported occurring after only 15 minutes' surgery. ${ }^{25}$ ) During surgery, a minimal amount of IV fluid should be given. Exposure of the capsule with opening of the venous sinuses occurs oniy at the end of the procedure if at all. Spinal anaesthesia is the method of choice: little anaesthetic is required, physiological disturbance is minimal, recognition of complications is not impaired and prompt therapy is possible. ${ }^{18}$ Postoperative IV infusion of large amounts of glucose solutions with a low sodium content will contribute to the dilution of the extracellular compartment. It is recommended that the postoperative IV fluid regimen be designed to maintain homeostasis and to produce adequate diuresis, for example with saline ${ }^{26}$ or Ringer's

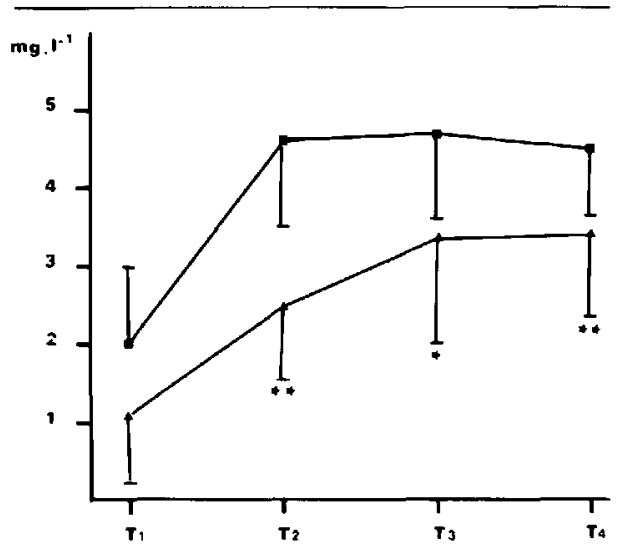

FIGURE 4 Free plasma bilirubin concentration, $\mathrm{mg} \cdot \mathrm{l}^{-1}$ (mean \pm SEM) at T1, T2, T3, T4; glycine 1.5 per cent. ${ }^{*} \mathrm{P}<0.05,{ }^{* * P}<0.01$, ***P $<0.001$.

lactate solution. ${ }^{2}$ Prophylaxis or treatment of the established case is controversial. Charlton ${ }^{19}$ recommended the administration of potent loop diuretics and hypertonic saline together with inotropes and calcium. Rhymer ${ }^{27}$ recommended the IV administration of $10 \mathrm{ml}$ of ten per cent calcium gluconate, a further dose of diuretic and restriction of fluids. In contrast, Bird et al. ${ }^{11}$ advised "masterly inactivity" by withdrawing all treatment and felt that the use of hypertonic solution was contraindicated because it might precipitate pulmonary oedema. The policy in our unit is to administer 100 to $200 \mathrm{ml}$ three per cent hypertonic saline solution when water is used, ${ }^{28}$ or hypertonic solution with furosemide at the end of the procedure when glycine 1.5 per cent is used. The postoperative IV infusion is modified according to urine output and CVP. If necessary inotropes such as dopamine or dobutamine are given. Using this regimen together with spinal anaesthesia the TURP syndrome has become a rare complication.

\section{References}

1 Creevy $C D$, Reiser $M P$. The importance of haemolysis in TUR severe and fatal reactions associated with the use of distilled water. J Urol 1963; 89: 900 .

2 Emmet $J L$, Gilbauch $J H, M c L e a n$ P. Fluid absorption during transurethral resection: comparison of mortality and morbidity after irrigation with water and non haemolytic solution. J Urol 1969; 101: 884-9.

3 Hoekstra PT, Kahnoski R, McCamish MA et al. Transurethral prostate resection syndrome. A new perspective: encephalopathy with associated hyperammonaemia. J Urol 1983; 130: 704-7. 
4 Ryder KW, Olson JF, Kahnoski RJ et al. Hyperammonaemia after transurethral resection of the prostate: a report of 2 cases. J Urol 1984; 132: 995-7.

5 Fitzpatrick JM, Kasidas GP, Rase GA. Hyperoxalaemia following glycine irrigation for transurethral prostatectomy. Br J Urol 1981; 53: 250-2.

6 Oester A, Madsen PO. Determination of absorption of irrigating fluid during transurethral resection of the prostate by means of radio-isotopes. J Urol 1969; 102: 714-9.

7 Hagstrom RS. Studies on fluid absorption during transurethral prostatic resections. J Urol 1955; 73: 852-9.

8 Sellevold $O$, Breivik $H$. Theter $K$. Changes in oncotic pressure, osmolality and electrolytes following transurethral resection of the prostate using glycine as irrigating solution. Scand J Urol Nephrol 1983; 17: 31-7.

9 Logie JRC, Keenan RA, Whitting PH et al. Fluid absorption during transurethral prostatectomy. Br J Urol 1980; 52: 526-8.

10 Robbins MA, Olson WH, Rolnick HC. Clinical observations on the use of a hemolytic and a non hemolytic irrigating medium for transurethral prostate resection. Surgery 1950; $27: 254-9$.

11 Bird D. Slade N, Feneley $B$. Intravascular complications of transurethral resection of the prostate. $\mathrm{Br} \mathrm{J}$ Urol 1982; 54: 564-5.

12 Madsen PO, Naber KG. Absorption and excretion of sorbitol and mannitol in transurethral resection of the prostate. Urology 1974; 11 : 331-5.

13 Still JA, Modell JH. Acute water intoxication during transurethral resection of the prostate, using glycine solution for irrigation. Anesthesiology 1973; 38: 98-9.

14 Stone AM et al. Renal vascular effects of stroma and stromafree hemoglobin. Surg Gyn Obst 1979; 149: 874-6.

15 Maluff NSR, Boren JS, Brandes GE. Absorption of irrigation solution and associated changes upon transurethral electroresection of prostate. J Urol 1956; 75 : 824-36.

16 Taylor RO, Maxson ES, Carter FH, Berthard WF, Prentiss $R J$. Volumetric, gravimetric and radioisotopic determination of fluid transfer in transurethral prostatectomy. J Urol 1958; 79: 490-9.

17 Zucker $J R$, Bull AP. Independent plasma levels of sodium and glycine during transurethral resection of prostate. Can Anaesth Soc J 1984; 31: 307-13.

18 Hatch $P D$. Surgical and anaesthetic considerations in transurethral resection of the prostate. Anaesth Intens Care 1987; 15: 203-11.

19 Charlion AJ. Cardiac arrest during transurethral prostatectomy after absorption of $1.5 \%$ glycine. Anaesthcsia 1980; 35: 804-6.

20 Garcias VA et al. Depressed myocardial function after transurethral resection of prostate. Urology 1981; 17 : $420-7$.
21 Mebust WK, Brady TW, Valk WL. Observations on cardiac output, blood volume, central venous pressure, fluid and electrolyte changes in patients undergoing transurethral prostatectomy. J Urol 1980; 103: 632-66.

22 Reiz $S$, Duchek $M$, Kernoff $Y$. Non cardiogenic pulmonary oedema. A serious complication of transurethral prostatectomy: a case report. Acta Anaesthesiol Scand 1981; 15 : 166-8.

23 Ovassapian A, Joshi CW, Brumer EA. Visual disturbances: an unusual symptom of transurethral prostatic resection reaction. Anesthesiology 1982; 57: 332-4.

24 Iglesias JJ. Comment Eviter le syndrome de résection transuréthrale de prostate. Ann Urol 1973; 7: 195-9.

25 Hurlbert $B J$, Wingard $D W$. Water intoxication after 15 minutes of transurethral resection of the prostate. Anesthesiology 1979; 50: 355-6.

26 Henderson $D J$, Middleton RG. Coma from hyponatremia following transurethral resection of prostate. Urology $1980 ; 15$ : 267-71.

27 Rhymer JC et al. Hyponatraemia following transurethral resection of the prostate. Brit J Urol 1985; 57: 450-2.

28 Avus JC, Olivero JJ, Frommer JP. Rapid correction of severe hyponatremia with intravenous hypertonic saline solution. Am J Med 1982; 72: 43-8.

\section{Résumé}

Cette étude prospective et randomisée a comparé les conséquences de deux liquides d'irrigation, l'eau distillée et le glycocolle au cours de la chirurgie prostatique par voie basse. Quarante-neuf patients consécutifs, non sélectionntés, bénéficiant d'une résection transuréthrale de prostate sous rachianesthésie, sont étudiés. Le liquide d'irrigation est soit l'eau distillée (groupe A, 24 patients), soit le glycocolle d 1.5 pour cent (groupe B, 25 patients). L'absorption des liquides d'irrigation, les incidents chirurgicaux et les signes cliniques du syndrome de réabsorption sont systématiquement notés.

Des signes caractéristiques du syndrome de réabsorption sont observés dans un cas dans le groupe A et dans quatre cas dans le groupe $B$ sans conséquence ultérieure. Seuls la protidémie, l'hématocrite, l'hémoglobine plasmatique libre et la bilirubine libre changent significativement. L'hémogiobine plasmatique libre augmente significativement dans les deux groupes, avec un taux plasmatique significativement plus élevé dans le groupe $A$.

Avec les deux liquides d' irrigation, on observe une hémolyse et une hémodilution sans conséquence clinique. Un temps de résection court, un faible niveau de pression d'irrigation. l'utilisation de l'anesthésie rachidienne nous semblent très importants. Une surveillance clinique et biologique attentive pendant et après la résection transuréthrale de prostate sont nécessaires; en revanche, le choix du liquide d'irrigation ne semble pas l'élément essentiel. 